\title{
Cocaine-induced vasculitis: is this a new trend?
}

This article was published in the following Dove Press journal:

Open Access Rheumatology: Research and Reviews

3 October 2013

Number of times this article has been viewed

\section{Miraida Reneé García \\ Pérez \\ Vanessa L Ortiz-González' \\ Maria Betancourt ${ }^{\prime}$ \\ Rogelio Mercado ${ }^{2}$}

'Department of Internal Medicine, San Juan City Hospital, ${ }^{2}$ Department of Dermatology, University of Puerto Rico School of Medicine, San Juan, Puerto Rico
Correspondence: Miraida Reneé García Pérez

San Juan City Hospital, Box 1926,

Arecibo 006/3, Puerto Rico

Email miraidarene@yahoo.com
Abstract: Cocaine-induced vasculitis is a rare complication found in drug abusers. It occurs due to cocaine adulterated with levamisole. Levamisole was once used as a chemotherapy and immunomodulator for different conditions. One of the side effects of this medication is necrotizing vasculitis which has been reported in the US and Puerto Rico. Here we present another case of cocaine induced vasculitis in Puerto Rico. We describe a 43-year-old female with past medical history of bronchial asthma, migraine, and crack smoking who presented to the emergency room due to blood in her urine for 5 days. She also reported fever, chills, and fatigue. At the physical exam she had a right knee ulcer with swelling erythema, warmth, and pain. Also, she had retiform purpuric plaque lesions in her ears, bilaterally. Eroded plaques with elevated borders at left foot and finger dorsum were also present. Laboratory workup was positive for cocaine. The patient showed leucopenia and microcytic anemia with a normal absolute neutrophil count in her cell blood count. Blood cultures, urine cultures, and ulcer cultures were negative. Urinalysis was positive for proteinuria and hematuria. Also, the patient had positive perinuclear anti-neutrophil cytoplasmic antibody, cytoplasmic anti-neutrophil cytoplasmic antibody, and antinuclear antibody tests and elastase specificity. She showed negative anticardiolipin and lupus anticoagulant antibodies. Her complement levels were decreased. The punch biopsy of her ear showed superficial thrombosis of superficial vascular plexus with perivascular lymphocytic infiltrates and deeper sections showed epidermal necrosis and necrotizing vasculitis. She was started on a high dose of steroids, but could not complete the treatment because she escaped from the hospital before finishing her treatment.

Keywords: levamisole, cocaine-induced vasculitis, vasculitis, P-ANCA, C-ANCA

\section{Introduction}

Cutaneous vasculitis occurs as a result of inflammatory processes that target and damage small or medium-sized blood vessels in the skin. A wide variety of disorders can lead to the development of cutaneous vasculitis. Infections and medications are the most common etiologies of cutaneous small vessel vasculitis. ${ }^{1}$ Cocaine can induce vasculitis. Over the years there have been some reports on this matter. What was once considered to be a very rare complication in drug abusers, now seems to be more common. Since $70 \%$ of the cocaine seized in the United States has been adulterated with levamisole, ${ }^{2}$ it's no wonder that there have been increased reports of vasculitis than in previous years. Here we report another case of vasculitis in Puerto Rico with anti-neutrophil cytoplasmic antibody (ANCA) positivity linked to cocaine use.

\section{Case report}

This is the case of a 43-year-old female with past medical history of bronchial asthma, migraine, and crack smoking, who came to San Juan City Hospital because she 
started to present blood in her urine 5 days prior. Also, she reported fever, chill, and fatigue. The patient also presented with right knee erythema, warmth, swelling, and pain. The knee pain was $8 / 10$ in intensity that increased when moving. The patient denied surgeries or traumas to the area. She also denied allergies and used no medications. Her history was remarkable for smoking crack daily for 30 years. Her last use was the day prior to admission. The physical exam showed bilateral purpuric macules in the ear helix; eroded plaques and elevated borders over the left foot; a $0.4 \mathrm{~mm}$ lesion at the finger dorsum; as well as vascular lesions in the knee and forearm (Figures 1 and 2). Toxicology was positive for cocaine. HIV test and hepatitis profile were nonreactive. Other laboratories showed increased levels of cytoplasmic ANCA (c-ANCA; $1.7 \mathrm{IU} / \mathrm{mL}$ ), perinuclear ANCA (P-ANCA; $1.7 \mathrm{IU} / \mathrm{mL})$, and antinuclear antibody (ANA; 3.1 units). Immunoglobulin G levels were 2,354 $\mathrm{mg} / \mathrm{dL}$ and immunoglobin $\mathrm{M}$ was $490 \mathrm{mg} / \mathrm{dL}$, which are both elevated. The ANA test showed homogenous pattern with titers $>1: 320$ Dils. ANCA specificities to neutrophil lactoferrin were negative, as well as to cathepsin G and lysozyme. However, an enzyme-linked immunosorbent assay for elastase was positive. Also, cryoglobulins were positive. Complement levels were decreased; $\mathrm{C} 3=81.9 \mathrm{mg} / \mathrm{dL}$ and $\mathrm{C} 4=13 \mathrm{mg} / \mathrm{dL}$. Anticardiolipin antibodies were negative (immunoglobin G: $9 \mathrm{U} / \mathrm{mL}$; immunoglobin A: $7.6 \mathrm{U} / \mathrm{mL}$; immunoglobin $\mathrm{M}: 8.2 \mathrm{U} / \mathrm{mL}$ ), as well as lupus anticoagulant. The patient had an elevated erythrocyte sedimentation rate of $107 \mathrm{~mm} /$ hour and an elevated C-reactive protein level of $72.3 \mathrm{mg} / \mathrm{L}$. The cell blood count showed leucopenia (white blood cell count $=4.5 \times 10^{3} / \mathrm{Ul}$ ), a microcytic anemia (hemoglobin $=9.2 \mathrm{~g} / \mathrm{dL}$, hematocrit $=28.2 \%$, mean cell volume $=71.39 \mathrm{fl}$, and red blood cell distribution

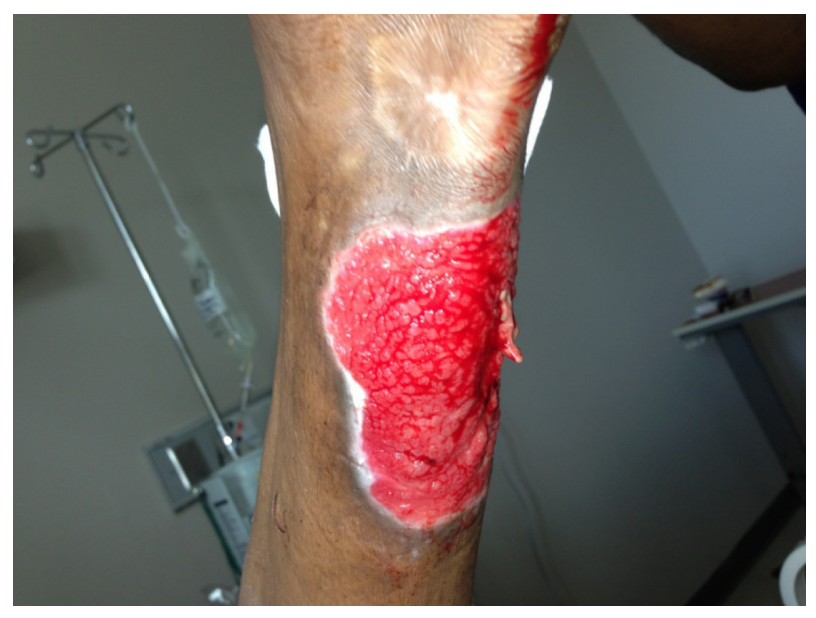

Figure I Patient's knee lesions after being curated by the enterostomal team.

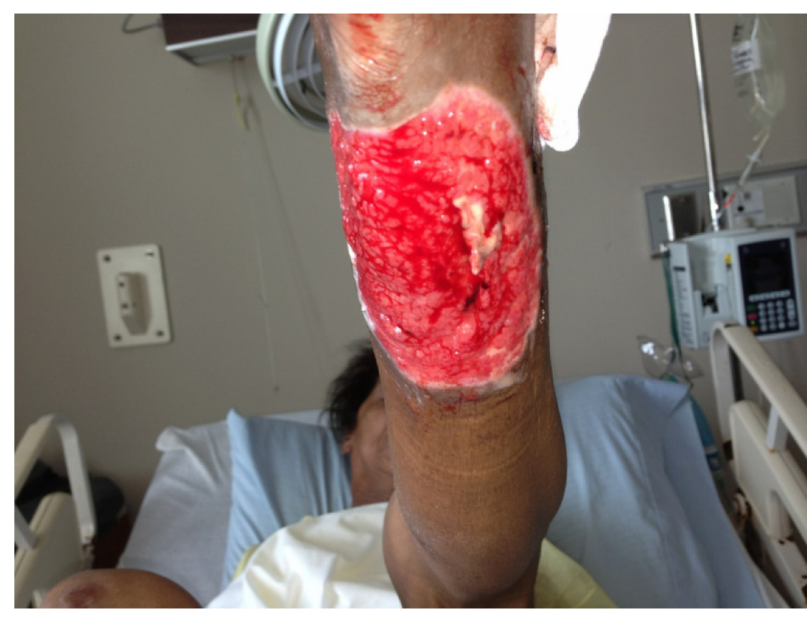

Figure 2 Patient's vascular lesions in the forearm after being cured by enterostomal care.

width $=19 \%$ ), and platelets of $183 \times 10^{3} \mathrm{uL}$. Her differential showed $75 \%$ neutrophils, $20 \%$ lymphocytes, $2 \%$ monocytes, and bands of $2 \%$ with an absolute neutrophil count of 3,465 cells $/ \mathrm{mm}^{3}$. Urinalysis came with proteinuria $(150 \mathrm{mg} / \mathrm{dL})$, occult blood $(250 \mathrm{uL})$, red blood cells (loaded - not countable/high power field), and many amorphous crystals. The punch biopsy of her ear showed superficial thrombosis of superficial vascular plexus with perivascular lymphocytic infiltrates and deeper sections showed epidermal necrosis and necrotizing vasculitis (Figure 3). Cultures of the ulcers came back with no organism growth. Also, blood cultures and urine culture were negative for an infective organism. This patient was started on a high dose of steroids, but didn't finish treatment since she escaped from the hospital.

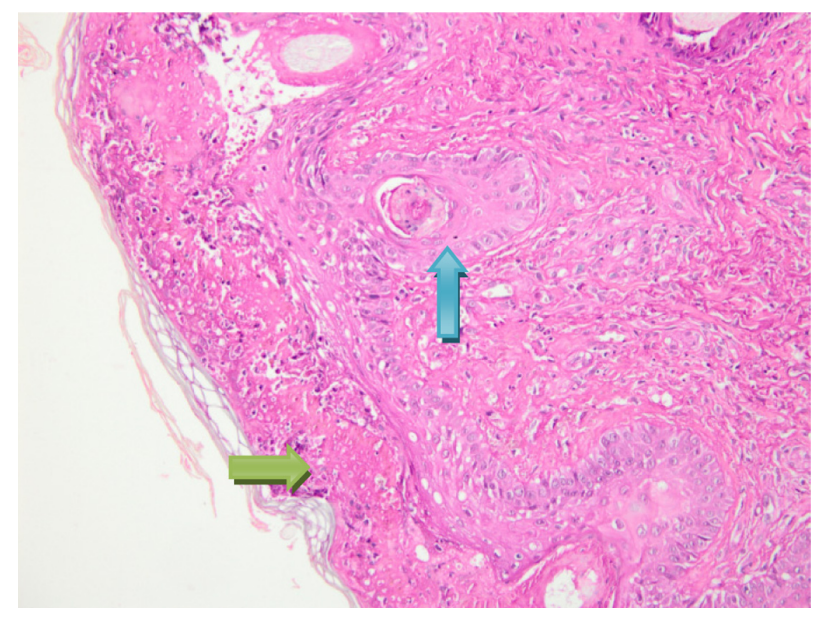

Figure 3 Skin biopsy of the patient's ear which shows superficial thrombosis of superficial vascular plexus (green arrow) with perivascular lymphocytic infiltrates and necrotizing vasculitis (blue arrow). 


\section{Discussion}

Levamisole-induced, occlusive, necrotizing vasculitis is an uncommon side effect of levamisole. Levamisole was previously used as an anthelmintic agent, in cancer therapy, and is still available as a veterinary deworming drug. ${ }^{3}$ Vasculitis presents as purpuric retiform lesions with necrotic patches typically manifesting on the ears and extremities. The lesions can be caused by inhaling or smoking cocaine. ${ }^{3}$ To the best of our knowledge, 33 cases have been reported of levamisole-induced vasculitis in patients using cocaine. The clinical findings on these patients were retiform purpuric plaques with ulceration and necrosis of the center. It usually affected the ear, face, chest, back, and upper and lower extremities. ${ }^{1,3-25}$ Some of the lesions were painful. The necrosis can be as extensive as to cover $35 \%$ of the body and can lead to amputation of the extremities. ${ }^{21,22}$ In this patient, she had lesions on her ears, upper extremity, and knee as mentioned previously. ANCAs (p-ANCA or both p-ANCA and c-ANCA), antiphospholipid antibodies, and leukopenia or neutropenia are frequently detected in patients with vasculitis or vasculopathy due to levamisole-contaminated cocaine as seen in this patient. ${ }^{1-4}$ In previous reports, there were 20 cases with reported leucopenia and neutropenia, but 13 cases with neither one of them. There is also a pattern of p-ANCA and c-ANCA antibodies in most of the cases, as in our patient. However, the specific antigens responsible for generating these positive ANCA fluorescent patterns are not yet clearly defined. ${ }^{3}$ In addition, immunoglobin $\mathrm{M}$ anticardiolipin antibodies were detected in most of the cases but not in our patient. Even though there is a tendency to have these markers, they are not specific for this kind of vasculitis as they can be seen in other diseases. Urine toxicology testing can confirm cocaine use by the patient in the preceding 2-3 days. Testing for levamisole in serum or urine is commercially available, but the short half-life of levamisole (5.6 hours) makes the drug difficult to detect. ${ }^{4}$ Although levamisole levels were not measured in this case due to the short half-life and the fact that a routine test for its detection is not commonly available, we believe it caused the clinical presentation of our patient. In the previously reported cases of levamisole-induced vasculitis, there was a predominance of female patients. It will be interesting to explore the epidemiological tendencies of these lesions, even though they can affect both males and females. Usually levamisole-induced vasculitis lesions resolve spontaneously after not using cocaine for couple of weeks. ${ }^{3}$ However, steroids have been used in some cases with success. ${ }^{8}$ But, the benefits of steroids are not clear to this day. Still, steroids were used in some of the previously reported cases with resolution within a week of use..$^{3-25}$ The most important thing that physicians should do is to inform patients to stop using cocaine or other illegal drugs. With this approach, cocaine-induced vasculitis would not be an issue in the future. The case presented will add more information to this trend seen in cocaine users, which can be useful for future research in specific findings of this type of patients.

\section{Acknowledgment}

We would like to thank Dr Rogelio Mercado for the biopsy images and the Department of Dermatology at University of Puerto Rico School of Medicine.

\section{Disclosure}

The authors report no conflicts of interest in this work.

\section{References}

1. Gross RL, Brucker J, Bahce-Altuntas A, et al. A novel cutaneous vasculitis syndrome induced by levamisole-contaminated cocaine. Clin Rheumatol. 2011;30(10):1385-1392.

2. Centers for Disease Control and Prevention (CDC). Agranulocytosis associated with cocaine use - four States, Mar 2008-Nov 2009. MMWR Morb Mortal Wkly Rep. 2009;58(49):1381-1385.

3. Abdul-Karim R, Ryan C, Rangel C, Emmet M. Levamisole-induced vasculitis. Proc (Bayl Univ Med Cent). 2013;26(2):163-165.

4. Chung C, Tumeh PC, Birnbaum R, et al. Characteristic purpura of the ears, vasculitis, and neutropenia - a potential public health epidemic associated with levamisole-adulterated cocaine. J Am Acad Dermatol. 2011;65(4):722-725.

5. Ullrich K, Koval R, Koval E, Bapoje S, Hirsh JM. Five consecutive cases of a cutaneous vasculopathy in users of levamisole-adulterated cocaine. J Clin Rheumatol. 2011;17(4):193-196.

6. McGrath MM, Isakova T, Rennke HG, Mottola AM, Laliberte KA, Niles JL. Contaminated cocaine and antineutrophil cytoplasmic antibodyassociated disease. Clin J Am Soc Nephrol. 2011;6(12):2799-2805.

7. Xu LY, Esparza EM, Anadkat MJ, Crone KG, Brasington RD. Cutaneous manifestations of vasculitis. Semin Arthritis Rheum. 2009;38(5):348-360.

8. Walsh NM, Green PJ, Burlingame RW, Pasternak S, Hanly JG. Cocaine-related retiform purpura: evidence to incriminate the adulterant, levamisole. J Cutan Pathol. 2010;37(12):1212-1219.

9. Buchanan JA, Vogel JA, Eberhardt AM. Levamisole-induced occlusive necrotizing vasculitis of the ears after use of cocaine contaminated with levamisole. J Med Toxicol. 2011;7(1):83-84.

10. Knowles L, Buxton JA, Skuridina N, et al. Levamisole tainted cocaine causing severe neutropenia in Alberta and British Columbia. Harm Reduct J. 2009;6:30.

11. Bradford M, Rosenberg B, Moreno J, Dumyati G. Bilateral necrosis of earlobes and cheeks: another complication of cocaine contaminated with levamisole. Ann Intern Med. 2010;152(11):758-759.

12. Chang A, Osterloh J, Thomas J. Levamisole: a dangerous new cocaine adulterant. Clin Pharmacol Ther. 2010;88(3):408-411.

13. Friedman DR, Wolfsthal SD. Cocaine-induced pseudovasculitis. Mayo Clin Proc. 2005;80(5):671-673.

14. Waller JM, Feramisco JD, Alberta-Wszolek L, McCalmont TH, Fox LP. Cocaine-associated retiform purpura and neutropenia: is levamisole the culprit? J Am Acad Dermatol. 2010;63(3):530-535.

15. Graf J. Rheumatic manifestations of cocaine use. Curr Opin Rheumatol. 2013;25(1):50-55.

16. Cocaine: Abuse and Addiction [webpage on the Internet]. Bethesda, MD: National Institute on Drug Abuse; 2010. Available from: http://www. drugabuse.gov/publications/research-reports/cocaine-abuse-addiction. Accessed August 21, 2013. 
17. Farhat EK, Muirhead TT, Chaffins ML, Douglass MC. Levamisoleinduced cutaneous necrosis mimicking coagulopathy. Arch Dermatol. 2010;146(11):1320-1321.

18. Click J. Levamisole-induced retiform purpura. J Drug Dermatol. 2011;10(2):217.

19. Geller L, Whang TB, Mercer SE, Phelps R. Retiform purpura: a new stigmata of illicit drug use? Dermatol Online J. 2011;17(2):7.

20. Han C, Sreenivasan G, Dutz JP. Reversible retiform purpura: a sign of cocaine use. CMAJ. 2011;183(9):E597-E600.

21. Ching JA, Smith DJ Jr. Levamisole-induced necrosis of skin, soft tissue, and bone: case report and review of literature. J Burn Care Res. 2012;33(1):e1-e5.

22. Mouzakis J, Somboonwit C, Lakshmi S, et al. Levamisole induced necrosis of the skin and neutropenia following intranasal cocaine use: a newly recognized syndrome. J Drugs Dermatol. 2011;10(10): 1204-1207.
23. Jacob RS, Silva CY, Powers JG, et al. Levamisole-induced vasculopathy: a report of 2 cases and a novel histopathologic finding. Am J Dermatopathol. 2012;34(2):208-213.

24. Lung D, Lynch K, Agrawal S, Armenian P, Banh K. Images in emergency medicine. Adult female with rash on lower extremities. Vasculopathic purpura and neutropenia caused by levamisole-contaminated cocaine. Ann Emerg Med. 2011;57(3):307, 311.

25. Zwang NA, Van Wagner LB, Rose S. A case of levamisole-induced systemic vasculitis and cocaine-induced midline destructive lesion: a case report. J Clin Rheumatol. 2011;17(4):197-200.

\section{Publish your work in this journal}

Open Access Rheumatology Research and Reviews is an international, peer-reviewed, open access journal, publishing all aspects of clinical and experimental rheumatology in the clinic and laboratory including the following topics: Pathology, pathophysiology of rheumatological diseases; Investigation, treatment and management of rheumatological diseases; Clinical trials and novel pharmacological approaches for the treatment of rheumatological disorders. The manuscript management system is completely online and includes a very quick and fair peerreview system, which is all easy to use. Visit http://www.dovepress.com/ testimonials.php to read real quotes from published authors. 